\title{
Chilean Teachers' Attitudes towards Inclusive Education, Intention, and Self-Efficacy to Implement Inclusive Practices
}

\author{
Constanza San Martin ${ }^{1, *(\mathbb{D})}$, Chenda Ramirez ${ }^{2}$, Rubén Calvo ${ }^{3}$, Yolanda Muñoz-Martínez ${ }^{4}(\mathbb{D}$ \\ and Umesh Sharma ${ }^{5}$ (D) \\ 1 Faculty of Education, Universidad Diego Portales, Santiago 8320000, Chile \\ 2 Centre of Inclusion and Social Innovation, Universidad Viña del Mar, Viña del Mar 2520000, Chile; \\ chenda.ramirez@uvm.cl \\ 3 Faculty of Geography, Catholic University of Chile, Santiago 8320000, Chile; rcalvo.gallardo@gmail.com \\ 4 Faculty of Education, University of Alcala, 28805 Madrid, Spain; yolanda.munozm@uah.es \\ 5 Faculty of Education, Monash University, Melbourne 3800, Australia; umesh.sharma@monash.edu \\ * Correspondence: constanza.sanmartin@mail.udp.cl
}

Citation: San Martin, C.; Ramirez, C.; Calvo, R.; Muñoz-Martínez, Y.;

Sharma, U. Chilean Teachers'

Attitudes towards Inclusive

Education, Intention, and

Self-Efficacy to Implement Inclusive

Practices. Sustainability 2021, 13, 2300.

https://doi.org/10.3390/su13042300

Academic Editor: Suvi Lakkala and

Edda Óskarsdóttir

Received: 29 January 2021

Accepted: 16 February 2021

Published: 20 February 2021

Publisher's Note: MDPI stays neutral with regard to jurisdictional claims in published maps and institutional affiliations.

Copyright: (c) 2021 by the authors. Licensee MDPI, Basel, Switzerland. This article is an open access article distributed under the terms and conditions of the Creative Commons Attribution (CC BY) license (https:/ / creativecommons.org/licenses/by/ $4.0 /)$.

\begin{abstract}
Teachers play an important role in the success of inclusive practices for diverse learners in regular classrooms. It is, therefore, important to examine their beliefs and preparation to teach in inclusive classrooms. The main purpose of this study was to analyze the attitude of active Chilean teachers $(n=569)$ towards inclusion, their self-efficacy regarding inclusive practices, and their intention to teach in inclusive classrooms. Our secondary objectives were to explore the relationship between their attitudes and self-efficacy and to determine the influence of demographic and professional variables on these two constructs. A positive and significant relationship between teachers' attitude and self-efficacy was found. Teacher qualification was not significantly related to attitudes towards inclusion but was negatively associated with their self-efficacy beliefs concerning inclusive practices. Secondary education teachers reported lower teaching efficacy beliefs for inclusion than pre-school, primary, and special education teachers. The type of school emerged as a significant predictor of teachers' attitude and self-efficacy beliefs. The implications of this research and need for additional teacher and in-service training to improve educators' attitudes and self-efficacy are discussed.
\end{abstract}

Keywords: attitudes; inclusive education; intentions; teaching efficacy

\section{Introduction}

Inclusive education (IE) refers to a form of education where all students, irrespective of their abilities, gender differences, socio-economic status, and other differences, participate, learn, and engage in a common learning environment [1]. The teacher takes on the primary responsibility for educating all children and ensuring that they are not excluded because of inappropriate curriculum and classroom practices [2,3]. Teachers need to be adequately prepared and supported to teach in inclusive classrooms [4]. IE is understood to go beyond approaches focused on disability or specific groups and, consequently, is one that seeks the development of an education based on human rights, dignity [5], equity, fairness, and justice [6,7]. From this perspective, inclusive education promotes the presence, participation, and learning of all through the implementation of inclusive values in educational cultures, policies, and practices [3]. Among these values, the authors explicitly refer to sustainability [8], since the challenge of education and one of its central purposes is to contribute to children having the general competences [9] and tools to develop a sustainable life in their territory [10], and to contribute to the quality of life and well-being of living beings, given that there is a relationship of interdependence with ecosystems. In this sense, inclusion becomes an "educational philosophy" [11] that promotes the appreciation and care of life in all its forms through processes that seek to reduce exclusion and suffering from a compassionate perspective [12]. 
Recently, the Global Education Monitoring Report [4], when referring to Latin America and the Caribbean, once again emphasized that implementing IE requires that all teachers are prepared to teach all students. This preparation is essential to achieve the fourth Sustainable Development Goal [5], which is aimed at ensuring inclusive, equitable, and quality education and to promote lifelong learning opportunities for all. Elements of this preparation include initial and continuous training, support for teachers, leading to attitudinal change in positive direction [13]. We believe attitudes on their own do not provide a complete picture about an individual teacher's capacity to teach in inclusive classrooms. They must also have a strong sense of teaching efficacy to teach learners with a wide range of diversities [13]. It is in this context that the present study was conducted. We examined teachers' attitudes, self-efficacy beliefs, and intention to include students with a variety of abilities in Chile.

\subsection{Inclusive Education in the Chilean Context}

Latin American education systems are seen as the most unequal in relation to other countries in the world [14]. In Chile, school segregation has negatively influenced students' access to learning opportunities [15]. The main factors related to the inequity in education are income per household, geographical area (i.e., rural/urban), ethnicity, gender, and disability [16]. This segregation is also generated by the characteristics of the Chilean social and educational system, which constitutes a paradigmatic case study characterized by the implementation of subsidies on demand, strong accountability, and market-oriented competition between schools, all of which have exacerbated educational segregation $[15,17]$. This scenario creates challenges for schools to transform into inclusive spaces that embrace diversity and develop an IE [3,4].

To move towards an increasingly inclusive educational system, the state of Chile has used public policy to reduce discrimination against groups considered minorities or vulnerable, for example, immigrants, people living in a difficult economic situation, people who have a non-heterosexual sexual orientation, people with a disability, and others (i.e., Decree 83/15; School Inclusion Law No. 20845; General Education Law No. 20370). In the educational field, especially students identified with special educational needs (SEN), one such policy in 1998 involved the creation of the School Integration Programs (PIE) in regular schools. It encompassed an increase in the resources available to promote quality educational processes in special schools [18]. In this context, Decrees 170 (2009) and 83 (2015) emphasized the different components for the establishment of an inclusive policy. The first decree incorporated transitory educational needs of students with attention difficulty disorder into the special grant [18]. It provided detailed guidelines for coteaching to create an enriched and transformative educational process [19]. The second decree focused on the diversification of teaching and curricular adjustments for preschool and basic education from the implementation of collaborative work strategies amongst teachers within the framework of the national curriculum [20]. This scenario encouraged and challenged teachers to adapt their practices in response to the diversity of their students and create opportunities under a common curriculum for all students [21].

Despite some remarkable advances in relation to the implementation of policies seeking to promote IE, there are still a few critical points to address, for example, the tension between the logic of educational integration and inclusion [18]. This has generated a segregated education that comes from a paradigm of compensatory support [22] and that is limited to the search for more adequate in-classroom teaching methodologies [23]. It ignores other relevant components of an inclusive education such as the relationship between students and teachers, their culture, and internal policies.

The development of IE requires supportive policies as well as availability of adequate resources and adequate teacher training consistent with its principles [6]. In relation to the latter, the Teacher Education and Development Study in Mathematics (TEDS-M) has reported substantial gaps in the knowledge of Chilean teachers [24]. In terms of IE, evidence indicates that some university programs incorporate inclusion topics just in spe- 
cific subjects; therefore, there are challenges with incorporating these elements into the initial teacher training process in a transversal way [21]. Studies show that teachers do not have sufficient expertise to develop educational practices that allow them to work in accordance with the diversity that exists in the classroom, due to infrequent or inadequate teacher training programs [25-27]. It is one of the main weaknesses acknowledged by many Chilean teachers themselves [28]: according to the Teaching and Learning International Survey (TALIS) results [29], 38\% of Chilean teachers indicated that they need more continuous training to work with students with special educational needs, compared to $22 \%$ reported by teachers in Organisation for Economic Co-operation and Development (OECD) countries.

To face these challenges, the Ministry of Education of Chile has developed teacher training programs with a central focus on teaching diversification processes, based on the principles of universal learning design and in collaborative works for the development of inclusive cultures, policies, and practices [3,30-33]. These efforts, which focused on the generation of collaborative educational communities and teacher training, are consistent with evidence indicating that teachers play a fundamental role in the development of an IE [33]. In this sense, what teachers believe and feel about IE and the way in which they perceive themselves professionally in front of the diversity of students has a fundamental role and directly affects their decisions, behaviors, and daily teaching practices.

\subsection{Teachers' Attitudes, Intention, and Self-Efficacy towards Inclusive Education}

Teachers are a key element of IE because their actions are expected to represent inclusive practices at schools [34]. For this reason, "teacher-related factors" have received significant research interest [35]. In this field of investigation, extensive previous research has shown that, together with the development of pedagogical skills and knowledge [36], positive teacher attitudes are essential for the success of all students in inclusive classrooms $[13,37-40]$.

Another frequently studied variable used to understand teachers' classroom practices is teaching self-efficacy [41,42]. This is understood as an individual's belief in their ability to organize and execute the courses of action required to successfully accomplish a specific teaching task in a particular context and which, therefore, constitutes a belief that influences motivation, actions, and teaching decisions [42,43]. Teachers with high levels of self-efficacy tend to seek different means to motivate and satisfy the needs of their students, including those who present barriers to development [44]. Therefore, the self-efficacy beliefs of teachers affect student learning [41]. In the field of IE, research carried out in a wide variety of contexts indicates that "inclusive teaching efficacy" consists of three sub-constructs, namely, inclusive teaching strategies, managing challenging behavior, and collaborative teaching $[45,46]$.

To understand the underlying elements of teachers' behavior in relation to the practices in the field of IE, studies have shown a virtuous and positive relationship between attitudes towards inclusive education and teachers' self-efficacy beliefs [46-49]. Consequently, teachers with high self-efficacy scores related to inclusion reported a more positive attitude towards inclusion in general [49], especially when considering the inclusion of students with disabilities [13,48,50,51].

Studies on IE have been developed based on the approaches of the theory of planned behavior (TPB), which claims that behavior is the product of the intention to act in a certain way [52]. In this regard, attitudes towards inclusion have been identified as a predictor of teachers' intentions in Chile [53] as well as other educational contexts [54-62]. These attitudes have also been associated with teaching behaviors [54,55,61-64].

Self-efficacy has been identified as a significant predictor of teachers' intentions [ $54,57,59-61]$ and behavior [54,55]. However, recent studies indicated that self-efficacy beliefs and attitudes do not directly influence teachers' practices [65], while other studies indicate that both constructs combined do influence the intentions of teachers and their practices $[53,59]$. 


\subsection{Effect of Teacher-Related Variables on Attitudes towards Self-Efficacy Beliefs about Inclusive Education}

Several studies have attempted to explore factors that could be related to teachers' attitudes [66] and self-efficacy towards IE. Avramidis and Norwich [37] conducted a literature review on this topic and identified three aspects that influence teachers' attitudes towards IE. The first refers to the characteristics of the students (e.g., nature of disability), the second to variables associated with teachers (age, gender, qualification, teaching experience), and the third to variables associated with the school (resources, educational environment, school leadership). Research indicates that, in terms of age and years of teaching experience, teachers' attitudes towards inclusion change over time [67]. Younger (aged 20 to 30 years) or inexperienced teachers maintain more favorable attitudes than teachers over 40 years old or with more years of teaching experience $[13,49,68]$. However, other studies found weak relationships for age and experience with educators' attitudes and self-efficacy beliefs related to IE [49].

Regarding the characteristics of teaching experience, some evidence indicates that having previous experience in inclusive classrooms, which is rated positively by teachers, is related to more positive attitudes [69,70]. Wilson et al. [61] report that teachers look at their past performance to determine how capable they see themselves and others when using inclusive teaching strategies. These findings highlight the importance of reciprocity, as described by the social cognitive theory between behavioral and personal factors, in which teachers can make decisions about their perceived ability based on past performance.

On the other hand, even when inclusion is not restricted to specific groups of students, there are studies that have examined the way in which the contact or relationship with people with disabilities $(\mathrm{PwD})$ can influence attitudes and self-efficacy towards IE. Studies show that close contact with people with disabilities and prior experience of teaching children with disabilities is associated with more positive attitudes towards inclusion $[60,69-73]$. Moreover, whether such experience is valued as positive or negative is one of the strongest predictors of educators' attitudes towards IE [74] and self-efficacy beliefs [75].

Gender has also been related to teachers' attitudes and self-efficacy beliefs towards inclusion. Several studies revealed that female teachers had more positive attitudes towards inclusive education [71,76,77]. However, Dorji et al. [72] and Ahmmed et al. [78] found that male teachers showed a significantly more positive attitude towards inclusion compared to female teachers. This variation in findings indicates that the influence of gender on attitudes towards inclusion are mixed [37], since some studies indicated that gender has no influence on these attitudes at all [79]. There are similar findings for self-efficacy related to inclusive practices [80], some studies finding an influence of gender [38,80], others $\operatorname{not}[67,81]$.

One of the variables related to the development of positive attitudes towards inclusion is teacher training. Evidence suggests that teachers with training on inclusion topics or special educational needs often have more positive attitudes than those without this training $[37,82,83]$. A teaching qualification also contributes to improving teachers' selfefficacy, via specific courses [80] or longer inclusive education training [84].

Regarding contextual elements at the school and the level of education at which the teachers perform, some studies show that primary school teachers have higher levels of self-efficacy beliefs than secondary school teachers [85]. Similar results were observed in Hong Kong by Chao et al. [80], who identified that primary school teachers exhibited higher levels of self-efficacy compared to secondary school teachers, especially in terms of the management of challenging behavior.

Research on attitudes, self-efficacy, and intentions for the development of inclusive educational practices in the South American context, particularly in Chile, is scarce. Recently, a study [53] validated instruments to measure attitudes, intention, and self-efficacy beliefs towards IE used in other world contexts to compare international evidence with what occurs in the Chilean context with in-service teachers. In this context and considering 
the challenges that arise from the structure and characteristics of the Chilean educational system for its teachers, it is necessary to collect evidence to further analyze these three constructs and their relationships among Chilean teachers. Based on the evidence, it will be possible to guide training processes to enable the development of an increasingly inclusive education.

\subsection{Aims and Objectives of Current Study}

The main purpose of this study was to analyze Chilean in-service teachers' attitudes towards inclusion, self-efficacy for inclusive practices, and intention to educate in inclusive classrooms. The secondary objectives were to explore the relationship between attitudes and self-efficacy and to determine the influence of demographic and professional variables on these two constructs. More specifically, the following three research questions were examined:

- What are Chilean teachers' attitudes towards inclusion, intention to educate in inclusive classrooms, and self-efficacy for inclusive practices?

- Is there a significant relationship between teachers' attitudes towards inclusion and self-efficacy for inclusive practices in Chile?

- Do the teachers' background variables influence attitudes towards inclusion and perceived self-efficacy for inclusive practices?

\section{Methods}

\subsection{Participants}

This study included 569 currently employed teachers working in schools sponsored by a public voucher system in both public (49\%) and subsidized private schools $(43.3 \%)$ and some working at private schools $(7.7 \%)$ in Chile. Of the respondents, a large majority $(80.1 \%)$ were females $(\mathrm{n}=456), 111$ were males $(19.5 \%)$, and two identified themselves with another gender $(0.35 \%)$. Participants included special education teachers $(38.7 \%)$, primary education teachers $(32.2 \%)$, and secondary education teachers $(20.4 \%)$. Most of the teachers knew people with disabilities $(92.3 \%)$. Table 1 shows details of the demographic and professional profile of the study participants.

Table 1. Description of Participants.

\begin{tabular}{|c|c|c|c|c|c|}
\hline $\begin{array}{c}\text { Socio-Demographic } \\
\text { Characteristics }\end{array}$ & $\mathbf{N}$ & $\%$ & $\begin{array}{c}\text { Socio-Demographic } \\
\text { Characteristics }\end{array}$ & $\mathbf{N}$ & $\%$ \\
\hline Type of school & & & $\begin{array}{l}\text { Geographical location in } \\
\text { Chile }\end{array}$ & & \\
\hline Special School & 127 & $22.3 \%$ & North & 80 & $14.1 \%$ \\
\hline Regular Primary School & 375 & $65.9 \%$ & Central & 397 & $69.8 \%$ \\
\hline High School & 56 & $9.9 \%$ & South & 92 & $16.2 \%$ \\
\hline Other type & 11 & $1.9 \%$ & & & \\
\hline Age & & & Teacher qualification & & \\
\hline $18-25$ years & 24 & 4.2 & Pre-School Teachers & 43 & 7.6 \\
\hline $26-35$ years & 185 & 32.5 & Teacher of specific subjects & 5 & 0.9 \\
\hline $36-45$ years & 161 & 28.3 & $\begin{array}{l}\text { Professional Technical } \\
\text { Teacher }\end{array}$ & 2 & 0.4 \\
\hline $46-55$ years & 127 & 22.3 & Primary Teacher & 183 & 32.2 \\
\hline $56-65$ years & 68 & 12.0 & Special Education Teacher & 220 & 38.7 \\
\hline 65 years or more & 4 & 0.7 & Secondary Teacher & 116 & 20.4 \\
\hline Academic Degree & & & Teaching experience & & \\
\hline Doctoral degree & 2 & 0.4 & $0-3$ years & 74 & 13.0 \\
\hline Bachelor's degree & 350 & 61.5 & $4-10$ years & 174 & 30.6 \\
\hline Master's degree & 125 & 22.0 & $11-20$ years & 175 & 30.8 \\
\hline Did not answer & 7 & 1.2 & $>20$ years & 146 & 25.7 \\
\hline Without academic degree & 85 & 14.9 & & & \\
\hline
\end{tabular}




\subsection{Participant Questionnaire}

An online questionnaire comprising four sections was used to collect data. The first section represented "Attitudes towards Inclusion Scale" (AIS), and it contained 8 items with responses on a seven-point Likert scale ( $1=$ totally disagree to $7=$ totally agree). This instrument was originally designed with 10 items, but two items were deleted at the time of scale validation $[53,59]$.

As indicated by a previous study with teachers in Chile, the AIS scale had two constructs, one related to beliefs on inclusion, another related to feelings about inclusion [53]. The second part consisted of an instrument with seven items to measure the "Intention to Teach in an Inclusive Classroom Scale" (ITICS). It also had a seven-point Likert type scale $(1=$ extremely unlikely to 7 = extremely likely) focused on action within the classroom [59]. The third part consisted of a "Teacher Efficacy for Inclusive Practices" (TEIP) scale [45] widely used across different international contexts [60,86-88]. The TEIP scale had a six-point Likert scale rating from $1=$ strongly disagree to $6=$ strongly agree, with 18 items comprising three factors: efficacy to use inclusive instruction, efficacy in collaboration, and efficacy in managing behavior.

Regarding the analysis of consistency and validity, results revealed that all three instruments had adequate reliability based on the Cronbach Alpha scores overall, as well as for the sub-scales, with values above 0.78 (AIS $=0.89$; ITICS $=0.85$; TEIP $=0.91$ ) [53].

All three instruments yield a total score, with higher scores indicative of more positive attitudes towards inclusion, a stronger intention to teach in an inclusive classroom, and higher levels of perceived teaching self-efficacy to teach in inclusive classrooms.

In the fourth part, demographic and professional information was requested from teachers (Table 1). The instruments were originally written in English for a previous study and were translated into Spanish for the Chilean study [53].

\subsection{Procedures}

The data were obtained from teachers working in private, public, and subsidized private Chilean schools. A link to the online questionnaire was forwarded by email to each school's principal registered in a database with participants from previous national studies. They were asked to share the link with the staff of teachers at each school. The study was conducted in accordance with the Declaration of Helsinki. Informed consent was incorporated into the questionnaire and was accepted by the participants before they accessed the instruments.

\subsection{Analysis}

The data were analyzed using SPSS statistical package version 24 and Stata 15. The validation of the scales for Chilean teachers was conducted using Cronbach Alpha and exploratory factor analysis (EFA), as described in a previous article [53]. Descriptive statistics were used to describe the level of attitudes towards inclusion (AIS), intention to educate in inclusive classrooms (ITICS), and self-efficacy for inclusive practices (TEIP) in a sample of Chilean teachers. Then, regression analyses were used to measure the relationship between teachers' attitudes towards inclusion and self-efficacy for inclusive practices in Chile. An ordinary least squares (OLS) regression model was used to quantify the effect of gender, age, teaching experience, teacher qualification, type of school, and contact with persons with disabilities on the attitudes and self-efficacy related to IE.

\section{Results}

\subsection{In-Service Teachers' Attitudes towards Inclusion}

The overall mean score of the AIS scale was 5.45 ( $S D=1.322$ ), suggesting that in-service teachers had a moderately positive attitude towards inclusion. In the subscale referring to feelings about inclusion, a higher mean score was observed $(M=5.70, C I$ [5.59-5.81], $\mathrm{SD}=1.348)$ if we compare it with the one referring to beliefs on inclusion $(\mathrm{M}=5.21$, CI [5.07-5.34], SD = 1.630). The belief that all students, regardless of their ability, should be 
taught in regular classrooms was the lowest $(M=4.77, S D=2.052)$ of the eight items of the scale (Table 2). However, attitudes about teaching students with a range of abilities in "my class" scored the highest $(\mathrm{M}=5.94, \mathrm{SD}=1.439)$.

Table 2. Teachers' attitudes toward inclusive education.

\begin{tabular}{cccc}
\hline Item & N & Mean & $\begin{array}{c}\text { Std. De- } \\
\text { viation }\end{array}$ \\
\hline $\begin{array}{c}\text { in regular classrooms. } \\
\text { I believe that all students regardless of their ability should be taught }\end{array}$ & 569 & 4.77 & 2.052 \\
$\begin{array}{c}\text { I believe that inclusion is beneficial to all students socially. } \\
\text { I believe that inclusion benefits all students academically. }\end{array}$ & 569 & 5.83 & 1.782 \\
$\begin{array}{c}\text { I believe that all students can learn in inclusive classrooms if their } \\
\text { teachers are willing to adapt the curriculum. }\end{array}$ & 569 & 5.95 & 1.984 \\
$\begin{array}{c}\text { I am pleased that I have the opportunity to teach students with } \\
\text { lower academic ability alongside other students in my class. }\end{array}$ & 569 & 5.67 & 1.842 \\
$\begin{array}{c}\text { I am excited to teach students with a range of abilities in my class. } \\
\text { I am pleased that including students with a range of abilities will } \\
\text { make me a better teacher. }\end{array}$ & 569 & 5.94 & 1.439 \\
$\begin{array}{c}\text { I am happy to have students who need assistance with their daily } \\
\text { activities included in my classrooms. }\end{array}$ & 569 & 5.76 & 1.880 \\
\hline
\end{tabular}

\subsection{In-Service Teachers' Intention to Educate in Inclusive Classrooms}

The overall mean score of the ITICS scale was 6.05 (SD = 0.997), suggesting that the Chilean in-service teachers in this study had a high positive intention to educate in inclusive classrooms. Intention means that item scores (Table 3) suggest that teachers claim to have more intention to seek information or advice from different actors of the school community in order to provide the necessary support for their students. This might include consulting with a colleague to identify possible ways to assist a struggling student in their class $(M=6.40, S D=1.123)$, consulting with the parents of a student who is struggling in their class $(\mathrm{M}=6.35, \mathrm{SD}=1.182)$, or consulting with a student who is displaying challenging behaviors to find out better ways to work with them $(M=6.30$, $\mathrm{SD}=1.184)$. Teachers were less likely to include students with severe disabilities in a range of social activities in their class $(\mathrm{M}=5.52, \mathrm{SD}=1.740)$ and change the curriculum to meet the learning needs of a student with learning difficulties enrolled in their class $(\mathrm{M}=5.59, \mathrm{SD}=1.553)$; the latter emerged as a relevant and necessary aspect to be developed with teachers, since adapting and adjusting the curriculum is one of the core elements of inclusive educational practices and, from a perspective of rights and equal opportunities for participation and learning perspective, constitutes one of the central roles of teachers in the current educational context.

\subsection{In-Service Teachers' Self-Efficacy for Inclusive Practices}

The overall mean score of the TEIP scale was $5.15(\mathrm{SD}=0.6053)$. Thus, teachers in this study had a relatively high level of self-efficacy for inclusive practices. As seen in Table 4, in general, the levels of perceived teaching efficacy related to managing behavior were the lowest $(M=5.10, S D=0.723)$, while the highest levels of confidence were related to the subscale of collaboration $(\mathrm{M}=5.31, \mathrm{SD}=0.681)$. The items with higher scores were related to collaborating with other professionals (e.g., itinerant teachers or speech pathologists) in designing educational plans for students with disabilities $(M=5.54, S D=0.775)$, the ability to get students to work together in pairs or in small groups $(\mathrm{M}=5.44, \mathrm{SD}=0.756)$, and to provide students with an alternative explanation when they were confused $(\mathrm{M}=5.44$, $\mathrm{SD}=0.757$ ). By contrast, the level of self-efficacy of Chilean in-service teachers to inform others about laws and policies relating to the inclusion of students with disabilities had the lowest mean response on the scale $(\mathrm{M}=4.47, \mathrm{SD}=1.420)$, followed by teachers level of confidence when dealing with students who are physically aggressive $(\mathrm{M}=4.78$, $\mathrm{SD}=1.195)$. 
Table 3. Teachers' intention to educate in inclusive classrooms scores.

\begin{tabular}{|c|c|c|c|}
\hline Item & $\mathbf{N}$ & Mean & $\begin{array}{l}\text { Std. De- } \\
\text { viation }\end{array}$ \\
\hline $\begin{array}{l}\text { Change the curriculum to meet the learning needs of a student } \\
\text { with learning difficulty enrolled in your class. }\end{array}$ & 569 & 5.59 & 1.553 \\
\hline $\begin{array}{c}\text { Consulting with the parents of a student who is struggling in } \\
\text { your class. }\end{array}$ & 569 & 6.35 & 1.182 \\
\hline $\begin{array}{l}\text { Consulting with your colleagues to identify possible ways you } \\
\text { can assist a struggling student in your class. }\end{array}$ & 569 & 6.40 & 1.123 \\
\hline $\begin{array}{l}\text { Undertake a professional development program, so you can } \\
\text { teach students with diverse learning needs well. }\end{array}$ & 569 & 6.02 & 1.480 \\
\hline $\begin{array}{l}\text { Consulting with a student who is displaying challenging } \\
\text { behaviors to find out better ways to work with him/her. }\end{array}$ & 569 & 6.30 & 1.184 \\
\hline $\begin{array}{c}\text { Include students with severe disabilities in a range of social } \\
\text { activities in your class. }\end{array}$ & 569 & 5.52 & 1.740 \\
\hline $\begin{array}{l}\text { Change the assessment tasks to suit the learning profile of a } \\
\text { student who is struggling (e.g., providing longer time to } \\
\text { complete the task or modifying test questions). }\end{array}$ & 569 & 6.19 & 1.354 \\
\hline
\end{tabular}

Table 4. Teachers' self-efficacy for inclusive practices scores.

\begin{tabular}{|c|c|c|c|}
\hline Item & $\mathbf{N}$ & Mean & Std. Deviation \\
\hline I can make my expectations clear about student behavior. & 569 & 5.31 & 0.902 \\
\hline I am able to calm a student who is disruptive or noisy. & 569 & 5.02 & 0.914 \\
\hline I can make parents feel comfortable coming to school. & 569 & 5.34 & 0.903 \\
\hline I can assist families in helping their children do well in school. & 569 & 5.19 & 0.953 \\
\hline I can accurately gauge student comprehension of what I have taught. & 569 & 4.93 & 0.901 \\
\hline I can provide appropriate challenges for very capable students. & 569 & 5.14 & 0.888 \\
\hline I am confident in my ability to prevent disruptive behavior in the classroom before it occurs. & 569 & 5.11 & 0.861 \\
\hline I can control disruptive behavior in the classroom. & 569 & 5.00 & 0.892 \\
\hline $\begin{array}{l}\text { I am confident in my ability to get parents involved in school activities of their children } \\
\text { with disabilities. }\end{array}$ & 569 & 5.08 & 0.927 \\
\hline $\begin{array}{l}\text { I am confident in designing learning tasks so that the individual needs of students with } \\
\text { disabilities are accommodated. }\end{array}$ & 569 & 5.01 & 01.022 \\
\hline I am able to get children to follow classroom rules. & 569 & 5.28 & 0.777 \\
\hline $\begin{array}{c}\text { I can collaborate with other professionals (e.g., itinerant teachers or speech pathologists) in } \\
\text { designing educational plans for students with disabilities. }\end{array}$ & 569 & 5.44 & 0.846 \\
\hline $\begin{array}{l}\text { I am able to work jointly with other professionals and staff (e.g., aides, other teachers) to } \\
\text { teach students with disabilities in the classroom. }\end{array}$ & 569 & 5.54 & 0.775 \\
\hline I am confident in my ability to get students to work together in pairs or in small groups. & 569 & 5.44 & 0.756 \\
\hline $\begin{array}{c}\text { I can use a variety of assessment strategies (e.g., portfolio assessment, modified tests, } \\
\text { performance-based assessment). }\end{array}$ & 569 & 5.20 & 1.000 \\
\hline $\begin{array}{l}\text { I am confident in informing others who know little about laws and policies relating to the } \\
\text { inclusion of students with disabilities. }\end{array}$ & 569 & 4.47 & 1.420 \\
\hline I am confident when dealing with students who are physically aggressive. & 569 & 4.78 & 1.195 \\
\hline I am able to provide an alternate explanation or example when students are confused. & 569 & 5.44 & 0.757 \\
\hline
\end{tabular}

\subsection{Relationship between Teachers' Attitudes towards Inclusion and Self-Efficacy for Inclusive Practices in Chile}

The results showed a significant relationship between teachers' attitude towards inclusion and self-efficacy for inclusive practices. As shown in Tables 5 and 6, the regression models indicate that TEIP has a positive influence on AIS $(\beta=0.68$, SE $=0.09)$ and that AIS has a positive influence on TEIP $(\beta=0.16, \mathrm{SE}=0.03)$, i.e., if attitudes towards inclusion are more positive, the self-efficacy for inclusive practices will also improve, and vice versa. 
Table 5. Regression model predicting overall attitude toward inclusive education.

\begin{tabular}{|c|c|c|c|c|c|}
\hline \multirow{2}{*}{ Variable } & \multirow{2}{*}{$\begin{array}{c}\text { Estimate } \\
(\beta)\end{array}$} & \multirow{2}{*}{ SE } & \multicolumn{2}{|c|}{$95 \% \mathrm{CI}$} & \multirow{2}{*}{$p$} \\
\hline & & & LL & UL & \\
\hline TEIP & $0.68^{* * *}$ & 0.09 & 0.51 & 0.86 & $<0.001$ \\
\hline \multicolumn{6}{|l|}{ Teaching experience } \\
\hline \multicolumn{6}{|c|}{ Reference category: 0 to 3 years of work experience } \\
\hline 4 to 10 years of work experience & -0.06 & 0.21 & -0.47 & 0.35 & 0.76 \\
\hline 11 to 20 years of work experience & -0.08 & 0.22 & -0.51 & 0.35 & 0.71 \\
\hline More than 20 years of work experience & 0.00 & 0.27 & -0.54 & 0.54 & 1.00 \\
\hline \multicolumn{6}{|l|}{ Contact with persons with disabilities } \\
\hline \multicolumn{6}{|l|}{ Reference category: No } \\
\hline Yes & 0.30 & 0.22 & -0.13 & 0.74 & 0.17 \\
\hline \multicolumn{6}{|l|}{ Teacher qualification } \\
\hline \multicolumn{6}{|l|}{ Reference category: Pre-school teacher } \\
\hline Other teacher & -0.27 & 0.53 & -1.31 & 0.78 & 0.62 \\
\hline Primary school teacher & -0.13 & 0.21 & -0.54 & 0.29 & 0.54 \\
\hline Special education teacher & 0.21 & 0.21 & -0.20 & 0.63 & 0.31 \\
\hline Secondary school teacher & -0.04 & 0.23 & -0.49 & 0.41 & 0.86 \\
\hline \multicolumn{6}{|l|}{ Age } \\
\hline \multicolumn{6}{|l|}{ Reference category: 18 to 25 years old } \\
\hline 26 to 35 years old & -0.32 & 0.29 & -0.89 & 0.25 & 0.27 \\
\hline 36 to 45 years old & -0.19 & 0.29 & -0.77 & 0.38 & 0.51 \\
\hline 46 to 55 years old & $-0.72 * *$ & 0.32 & -1.35 & -0.09 & 0.03 \\
\hline 56 to 65 years old & $-0.77^{* *}$ & 0.37 & -1.49 & -0.05 & 0.04 \\
\hline More than 65 years old & 0.16 & 0.40 & -0.63 & 0.94 & 0.70 \\
\hline \multicolumn{6}{|l|}{ Gender } \\
\hline \multicolumn{6}{|l|}{ Reference category: Male } \\
\hline Female & -0.16 & 0.15 & -0.46 & 0.14 & 0.28 \\
\hline Other genders & $1.70^{* * *}$ & 0.21 & 1.29 & 2.11 & $<0.001$ \\
\hline \multicolumn{6}{|l|}{ Type of school } \\
\hline \multicolumn{6}{|l|}{ Reference category: Special School } \\
\hline Mainstream Primary School & $1.27^{* * *}$ & 0.16 & 0.97 & 1.58 & $<0.001$ \\
\hline High School & $1.45^{* * *}$ & 0.21 & 1.05 & 1.86 & $<0.001$ \\
\hline Other & $1.44^{* * *}$ & 0.33 & 0.79 & 2.09 & $<0.001$ \\
\hline Intercept & 1.22 & 0.62 & 0.01 & 2.44 & 0.05 \\
\hline
\end{tabular}

Control variables: Academic degree, level of knowledge of educational inclusion policies, level of confidence to teach students with a disability

$\begin{array}{ll}\text { Observations } & 569 \\ \text { Adjusted R2 } & 0.26\end{array}$

Note: SE indicates the standard error. LL and UL indicate the lower and upper limits of a confidence interval, respectively. ${ }^{* *} p<0.05$, $* * * p<0.01$. 
Table 6. Regression model predicting overall teacher self-efficacy for inclusive practices.

\begin{tabular}{|c|c|c|c|c|c|}
\hline \multirow{2}{*}{ Variable } & \multirow{2}{*}{$\begin{array}{c}\text { Estimate } \\
(\beta)\end{array}$} & \multirow{2}{*}{ SE } & \multicolumn{2}{|c|}{$95 \% \mathrm{CI}$} & \multirow{2}{*}{$p$} \\
\hline & & & LL & UL & \\
\hline AIS & $0.16^{* * *}$ & 0.03 & 0.10 & 0.22 & $<0.001$ \\
\hline \multicolumn{6}{|l|}{ Teaching experience } \\
\hline \multicolumn{6}{|c|}{ Reference category: 0 to 3 years of work experience } \\
\hline 4 to 10 years of work experience & 0.10 & 0.10 & -0.09 & 0.29 & 0.31 \\
\hline 11 to 20 years of work experience & 0.05 & 0.10 & -0.16 & 0.25 & 0.64 \\
\hline More than 20 years of work experience & 0.13 & 0.14 & -0.15 & 0.41 & 0.37 \\
\hline \multicolumn{6}{|l|}{ Contact with persons with disabilities } \\
\hline \multicolumn{6}{|l|}{ Reference category: No } \\
\hline Yes & 0.21 & 0.11 & -0.01 & 0.44 & 0.07 \\
\hline \multicolumn{6}{|l|}{ Teacher qualification } \\
\hline \multicolumn{6}{|l|}{ Reference category: Pre-school teacher } \\
\hline Other teacher & -1.01 & 0.51 & -2.01 & -0.02 & 0.05 \\
\hline Primary school teacher & -0.06 & 0.09 & -0.24 & 0.13 & 0.54 \\
\hline Special education teacher & -0.17 & 0.09 & -0.35 & 0.02 & 0.08 \\
\hline Secondary school teacher & $-0.24^{* *}$ & 0.11 & -0.45 & -0.03 & 0.02 \\
\hline \multicolumn{6}{|l|}{ Age } \\
\hline \multicolumn{6}{|l|}{ Reference category: 18 to 25 years old } \\
\hline 26 to 35 years old & 0.14 & 0.18 & -0.22 & 0.50 & 0.44 \\
\hline 36 to 45 years old & 0.19 & 0.19 & -0.18 & 0.56 & 0.31 \\
\hline 46 to 55 years old & 0.26 & 0.21 & -0.15 & 0.66 & 0.21 \\
\hline 56 to 65 years old & 0.28 & 0.22 & -0.16 & 0.71 & 0.21 \\
\hline More than 65 years old & 0.49 & 0.36 & -0.22 & 1.21 & 0.18 \\
\hline \multicolumn{6}{|l|}{ Gender } \\
\hline \multicolumn{6}{|l|}{ Reference category: Male } \\
\hline Female & $0.14^{* *}$ & 0.07 & 0.00 & 0.28 & 0.05 \\
\hline Other genders & $-1.11^{* * *}$ & 0.10 & -1.30 & -0.92 & $<0.001$ \\
\hline \multicolumn{6}{|l|}{ Type of school } \\
\hline \multicolumn{6}{|l|}{ Reference category: Special School } \\
\hline Mainstream Primary School & $-0.20 * *$ & 0.08 & -0.36 & -0.05 & 0.01 \\
\hline High School & $-0.23^{* *}$ & 0.11 & -0.45 & -0.01 & 0.04 \\
\hline Other & $-0.38^{* *}$ & 0.17 & -0.70 & -0.05 & 0.02 \\
\hline Intercept & 3.99 & 0.27 & 3.47 & 4.52 & $<0.001$ \\
\hline
\end{tabular}

Control variables: Academic degree, level of knowledge of educational inclusion policies, level of confidence to teach students with a disability

$\begin{array}{ll}\text { Observations } & 569 \\ \text { Adjusted R2 } & 0.56\end{array}$

Note: SE indicates the standard error. LL and UL indicate the lower and upper limits of a confidence interval, respectively. ${ }^{* *} p<0.05$, *** $p<0.01$.

3.5. Influence of Demographic Variables on Teachers' Attitudes towards Inclusion, Intention to Educate in Inclusive Classrooms, and Self-Efficacy Regarding Inclusive Practices

Here, we present results showing which individual and institutional characteristics have an effect on attitudes towards inclusion (AIS), intention to educate in inclusive classrooms (ITICS), and teacher efficacy for inclusive practices (TEIP). Tables 5 and 6 present the results of a series of OLS regression models with AIS and TEIP as the dependent variables in two separate models and a set of individual and institutional variables as the explanatory variables.

The results show that teaching experience and contact with people with disabilities had no effect on AIS and TEIP scores in our sample of in-service Chilean teachers. However, the teachers' gender had a significant effect, with female teachers tending to have a higher score on the TEIP scale. The category "other genders" had a negative impact on TEIP and a positive impact on AIS, although this group represented a small percentage of the sample 
$(0.35 \%)$. Thus, results should be carefully interpreted, and further research is encouraged to supply more evidence. The same applies for each age group, since our results indicate that age had no effect on AIS and a negative impact on TEIP is observed, as older age groups (more than 46 years) tend to show lower level of self-efficacy regarding inclusive practices $(-0.721, p<0.05)$ compared to the reference group (18-25 years old).

In terms of individual characteristics, whether teachers held a qualification had no effect on AIS but had a negative effect on the TEIP score. Therefore, secondary teachers report less self-efficacy for inclusive practices than pre-school, primary teachers, and special educators. The type of schools where teachers work then emerges as an interesting explaining variable. In this way, working at mainstream primary schools $\left(1.27^{* * *}\right)$ and high schools $\left(1.45^{* * *}\right)$ has a positive effect on attitudes towards inclusion (AIS), in comparison with teachers who work in special schools. However, concerning self-efficacy for inclusion (TEIP), teachers who work in a special school have a higher level of self-efficacy for inclusive practices compared to mainstream schools.

\section{Discussion}

This research extends and contributes to previous work carried out in South America in three ways. First, it assesses different aspects of Chilean teachers', namely, attitudes towards inclusion, intention to educate in inclusive classrooms, and self-efficacy for inclusive practices. Second, it examines the relationship between attitudes and self-efficacy. Third, it explores the relationship between teachers' demographic attributes, their work environment, and whether these can predict teachers' attitudes towards inclusion and self-efficacy for inclusive practices. Our results indicate that the Chilean in-service teachers who participated in this study maintain a moderately positive attitude towards inclusion when taken as a whole. Nevertheless, our results are consistent with other studies, which indicated that teachers generally hold more negative or neutral attitudes towards the inclusion of pupils with disabilities in the regular education system $[39,49]$. This was also observed in relation to the intentions to develop an education in inclusive classrooms. Findings show that teachers were less favorable to include students with severe disabilities in social activities in their class. This accounts for a differentiation in attitudes towards inclusion and intentions to develop an inclusive education based on the characteristics of the students [37]. In this sense, it becomes evident that segregated spaces are still considered an option for students with severe disabilities.

On the other hand, our results indicate the presence of favorable intentions towards the development of an education in inclusive classrooms, particularly with regard to collaborating with and seeking guidance from different actors within the school community in order to provide the necessary support to students. However, the central focus of the development of inclusive practices is based on the idea of changing and adapting the teaching practices themselves to respond to the diversity of students' needs [89]. Teachers were less inclined to change the curriculum to meet the learning needs of their students when compared with the other areas measured using the ITICS scale. This indicates that it is necessary to develop training processes that allow teachers to visualize the diversification and flexibility of teaching as a fundamental part of the teaching role, as well as to develop tools and skills to perform this aspect of the role in their daily educational practices, with particular emphasis on the development of collaboration skills [49].

The teachers in this study had a high level of self-efficacy related to inclusive practices compared to the overall results obtained in other countries, where the TEIP scale was used such as Japan [13], South Africa, and Finland [49], and even higher than pre-service teachers from Mexico [90]. However, these results should be analyzed with caution, given that they are based on general averages containing variations in the subscales and specific items. Importantly, the results provide us with information that may be useful for the development of teacher training processes. In this regard, these findings reveal an actual need in terms of knowledge and management of laws and policies related to inclusive education. 
Although Chile has made progress in inclusion policies, these have not been characterized as the result of a process in which teachers have actively participated. This has likely contributed to the fact that teachers have not yet been able to internalize these policies in a way that makes them feel confident.

Furthermore, our results allow us to visualize that, as in other educational contexts, behavior management and dealing with aggressive expressions of behavior constitute a complex aspect in which teachers perceive themselves as less effective. This suggests that Chilean universities with teaching training programs have work to do to develop the training on topics concerning school coexistence and conflict management [91].

Regarding the second research question tackled by this study, we observed a significant relationship between teachers' attitudes towards inclusion and self-efficacy for inclusive practices in Chile, similar to previous studies [46-48]. Teachers' attitudes towards inclusion (AIS) have a positive effect on self-efficacy for inclusive practices (TEIP) and vice versa. These results are similar to those obtained by previous studies developed in different educational contexts and highlight the importance of the development of both elements, and as shown by studies developed in Chile, India and Australia, these findings do have an impact and predict the intention of teachers to educate in inclusive classrooms $[53,59]$. A contribution of our work is that both effects were identified by controlling a set of sociodemographic variables, which reduced the source of endogeneity. These findings and other previous studies indicate that attitudes towards inclusion and self-efficacy for inclusive practices have a positive effect on the intention of implementing inclusive practices within the classroom $[53,59]$. This provides extra incentives for teacher training, as if actions that contribute to improve the self-efficacy for inclusive practices are carried out, they will also be contributing to a positive change in attitudes and intentions that, in turn, have a positive effect on the decisions and behaviors related to educational practices [9] that contributes to inclusive education.

Regarding the influence of demographic and professional characteristics of the teachers in the two constructs at the center of the analysis conducted in this study, the results indicate that pre-school, primary, and special education teachers have higher levels of self-efficacy in terms of teaching than secondary school teachers. This difference between primary and secondary teachers has been reported in previous studies $[80,85,92]$. These findings are probably related to the type of training that secondary school teachers receive, which tends to be focused on disciplinary knowledge and specialized learning outcomes rather than on an inclusive pedagogy that allows for adjustments and adaptation of pedagogical decisions and practices according to the diversity of students. For this reason, in order to develop an increasingly inclusive educational system, teacher training is critical [93], as various studies have reported its relationship with the development of positive attitudes towards inclusion $[82,83,94]$ and high level of teachers' self-efficacy beliefs $[38,80]$. Thus, teacher training processes must emphasize and promote the development of positive attitudes towards inclusion $[37,39]$ due to the repercussions this has on self-efficacy beliefs and teaching behavior in the classroom $[95,96]$.

Variables referring to the type of school where teachers work provided a novel result that needs to be explored in greater depth. It was found that teachers with a less favorable attitude towards inclusion were most likely to work in special schools in the Chilean context. However, working in this type of school has a positive effect on the perception of self-efficacy for inclusive practices. In this regard, it is possible to hypothesize that the less positive attitudes of these teachers towards inclusion in regular schools may be associated with the special characteristics of the Chilean educational system and its schools, as diagnostic criteria for the delivery of resources and supports still predominate within the framework of the School Integration Program, which contributes to the stigmatization of students identified with SEN. In addition, studies indicate high levels of violence and bullying in regular schools, as well as large classrooms and teachers who do not feel trained to meet the needs of their students and who are, therefore, resistant to diversity [97]. These contextual elements probably influence these less favorable attitudes towards inclusion. 
On the other hand, the daily performance within special schools, where the context is constantly challenging their teachers in the search for adaptation, support, and innovation to allow them to generate learning and participation opportunities for students with disabilities, can be a factor that contributes to a higher perception of self-efficacy for those who work there. However, these are only hypotheses, and it is necessary to research to understand these results from the perspective of special education teachers who work in special schools.

Our results indicated that age had a negative effect on participants' attitudes. As the age of the teacher increased, they became less favorable in their attitudes towards inclusion. Female teachers reported a greater perception of self-efficacy. Both of these results coincide with those obtained in other research, although the literature has shown variation in different populations and educational contexts $[13,37,66]$.

Finally, our analysis showed that self-efficacy and attitude scores were not significantly related to the academic degree, contact with persons with disabilities, years of teaching experience, level of knowledge of educational inclusion policies, or level of confidence to teach students with a disability. In this context, our results speak of a certain homogeneity among teachers in the Chilean educational context, and regardless of these demographic characteristics, teachers maintain more or less the same attitudes and sense of self-efficacy towards inclusive education. These results differ from results obtained by other studies of both pre-service and in-service teachers [98], in which these three variables were identified as predictors of teaching efficacy beliefs.

\section{Study Limitations}

The present study has some limitations that need to be specified. First, the study was conducted using just self-report instruments so the results could be influenced by social desirability bias, and the results should be interpreted considering these characteristics. Second, in our study, a low percentage of participants were working in private schools. Therefore, it is necessary to carry out future studies that include a greater number of teachers from this population of teachers, as well as to consider, for example, other characteristics of schools such as whether they are in urban or rural areas and local levels of social vulnerability, among others, which would allow us to understand how the characteristics of the educational environment can influence teachers' attitudes, self-efficacy, and intentions relating to the development of inclusive practices.

\section{Conclusions}

In this study, we found a significant relationship between teachers' attitudes towards inclusion and self-efficacy for inclusive practices. Our results show a certain homogeneity among teachers in the Chilean educational context, as regardless of the variation in some demographic characteristics, teachers maintain more or less the same attitudes and sense of self-efficacy towards inclusive education. In terms of individual characteristics, the results showed that teacher qualification has no effect on attitudes towards inclusion (AIS) but has a negative effect on the self-efficacy score for inclusive practices (TEIP). Secondary education teachers reported lower self-efficacy for inclusive practices than preschool, primary, and special educators.

The type of school where teachers work emerged as an important predictor variable. Working in ordinary primary and secondary schools has a positive effect on attitudes towards inclusion when compared to teachers working in special schools. However, working in special schools has a positive effect on self-efficacy for inclusion. Finally, it is important to note that teachers continue to have a less favorable attitude towards the inclusion of students with severe disabilities and challenging behaviors. The results of this study indicate that more attention should be paid to generating training processes for teachers regarding three fundamental characteristics: the importance of the curriculum and its flexibility, the laws and regulations on inclusive education and disability, and peaceful coexistence and conflict resolution in the classroom. 
The results have implications for the design and implementation of public policies in the school system and in the training of teachers. In both sectors, it is urgent to have policies that aim at a transversal and sustained development of an IE that allows for the strengthening of the teaching profession to make teaching more flexible and diversified from a rights perspective. The results reveal a need to analyze the impacts of the approaches underlying current educational policies in this area that, although they seek to advance towards an inclusive education, are not exempt from dilemmas and paradoxical contradictions.

Author Contributions: Conceptualization, C.S.M., C.R., and U.S.; methodology, R.C. and C.S.M.; formal analysis, R.C. and Y.M.-M.; investigation, C.S.M.; data curation, C.S.M. and Y.M.-M.; writingoriginal draft preparation, C.S.M. and C.R.; writing-review and editing, U.S. and Y.M.-M.; visualization, C.S.M. and R.C.; project administration, C.S.M. All authors have read and agreed to the published version of the manuscript.

Funding: This research received no external funding.

Institutional Review Board Statement: The study was conducted according to the guidelines of the Declaration of Helsinki, and approved by the Ethics Committee of Faculty of Education of Universidad Diego Portales on 19 August 2018.

Informed Consent Statement: Informed consent was obtained from all subjects involved in the study. Data Availability Statement: Not applicable.

Acknowledgments: We would like to thank all the teachers participating in this study, who every day make efforts to promote the learning of their students.

Conflicts of Interest: The authors declare no conflict of interest.

\section{References}

1. AuCoin, A.; Porter, G.; Baker-Korotkov, K. New Brunswick's journey to inclusive education. Prospects 2020. [CrossRef]

2. Ismailos, L.; Gallagher, T.; Bennett, S.; Li, X. Pre-service and in-service teachers' attitudes and self-efficacy beliefs with regards to inclusive education. Int. J. Incl. Educ. 2019. [CrossRef]

3. Booth, T.; Ainscow, M. Index for Inclusion Developing Learning and Participation in Schools; Centre for Studies on Inclusive Education: Bristol, UK, 2011.

4. UNESCO. Global Education Monitoring Report 2020: Inclusion and Education: All Means all; UNESCO: London, UK, 2020.

5. UNESCO. Education 2030: Incheon Declaration and Framework for Action for the Implementation of Sustainable Development Goal 4; UNESCO: London, UK, 2016.

6. Ainscow, M. Promoting inclusion and equity in education: Lessons from international experiences. Nord. J. Stud. Educ. Policy 2020, 6, 7-16. [CrossRef]

7. Slee, R. Belonging in an age of exclusion. Int. J. Incl. Educ. 2019, 23, 909-922. [CrossRef]

8. Echeita, G.; Navarro, D. Educación inclusiva y desarrollo sostenible: Una llamada urgente a pensarlas juntas. Edetania Estud. Propues. Socio-Educ. 2014, 46, 141-162.

9. Daujotiené, L.; Kazlauskiené, A.; Bubnys, R. Teacher Involvement in Organisational Change: From engaging risk to Cooperative Learning. Sustainability 2020, 12, 9447. [CrossRef]

10. Tikly, L. Education for Sustainable Development in the Postcolonial World: Towards a Transformative Agenda for Africa; Routledge: New York, NY, USA, 2019.

11. Göransson, K.; Nilholm, C. Conceptual diversities and empirical shortcomings-A critical analysis of research on inclusive education. Eur. J. Spec. Needs Educ. 2014, 29, 265-280. [CrossRef]

12. Gilbert, P. The Compassionate Mind: A New Approach to Life's Challenges; New Harbinger Publications: Oakland, CA, USA, 2009.

13. Yada, A.; Savolainen, H. Japanese in-service teachers' attitudes towards inclusive education and self-efficacy for inclusive practices. Teach. Teach. Educ. 2017, 64, 222-229. [CrossRef]

14. Calderón-Almendros, I.; Ainscow, M.; Bersanelli, S.; Molina-Toledo, P. Educational inclusion and equity in Latin America: An analysis of the challenges. Prospects 2020, 9, 169-186. [CrossRef]

15. Valenzuela, J.P.; Bellei, C.; De los Ríos, D. Socioeconomic school segregation in a market-oriented educational system. The case of Chile. J. Educ. Policy 2014, 29, 217-241. [CrossRef]

16. de Medrano Ureta, C. Cómo prevenir el rechazo y la exclusión social. Cuad. Pedagog. 2005, 348, 58-61.

17. Villalobos, C.; Quaresma, M. Sistema escolar chileno: Características y consecuencias de un modelo orientado al mercado. Convergencia 2015, 22, 63-84. [CrossRef]

18. López, V.; González, P.; Manghi, D.; Ascorra, P.; Oyanedel, J.C.; Redón, S.; Salgado, M. Políticas de inclusión educativa en Chile: Tres nudos críticos. Arch. Analíticos Políticas Educ. 2018, 26. [CrossRef] 
19. Figueroa, I.; Sepúlveda, G.; Soto, J.; Yáñez, C. Coenseñanza entre docentes de educación general básica y educadoras diferenciales: Incidentes críticos de la práctica colaborativa en proyectos de integración educativa. Pensam. Educ. Rev. Investig. Educ. Latinoam. 2020, 57, 1-15.

20. Ministerio de Educación de Chile. Orientaciones Sobre Estrategias Diversificadas de Enseñanza Para Educación Básica, en el Marco del Decreto 83/2015. 2017. Available online: https:/ / bibliotecadigital.mineduc.cl/handle/20.500.12365/2122 (accessed on 16 July 2020).

21. San Martin, C.; Salas, N.; Howard, S.; Blanco, P. Acceso al currículum nacional para todos: Oportunidades y desafíos de los procesos de diversificación de la enseñanza en escuelas diferenciales chilenas. Rev. Latinoam. Inclusión Educ. 2017, 11, 181-198. [CrossRef]

22. Manghi, D.; Solar, M.L.C.; Ibarra, A.B.; Godoy, I.A.; Córdova, V.V.; Soto, K.D. Understanding inclusive education in Chile: An overview of policy and educational research. Cad. Pesqui. 2020, 50, 114-134. [CrossRef]

23. Peña, M. Análisis crítico de discurso del decreto 170 de subvención diferenciada para necesidades educativas especiales: El diagnóstico como herramienta de gestión. Psicoperspectivas 2013, 12, 9-103. [CrossRef]

24. Tatto, M.T.; Peck, R.; Schwille, J.; Bankov, K.; Senk, S.L.; Rodriguez, M.; Rowley, G. Policy, Practice, and Readiness to Teach Primary and Secondary Mathematics in 17 Countries: Findings from the IEA Teacher Education and Development Study in Mathematics (TEDS-MM); International Association for the Evaluation of Educational Achievement: Amsterdam, The Netherlands, 2012.

25. Ávalos, B.; Matus, C. La Formación Inicial Docente en Chile Desde una Óptica Internacional: Informe Nacional del Estudio Internacional IEA TEDS-M; Ministerio de Educación: Santiago, Chile, 2010.

26. Ávalos, B.; Navarro, S.; Téllez, F. Learning about the effectiveness of teacher education: A Chilean study. Perspect. Educ. 2010, 28, $11-21$.

27. Sotomayor, C.; Parodi, G.; Coloma, C.; Ibáñez, R.; Cavada, P. La formación inicial de docentes de Educación General Básica en Chile. ¿Qué se espera que aprendan los futuros profesores en el área de Lenguaje y Comunicación? Pensam. Educ. 2011, 48, 28-41. [CrossRef]

28. Rufinelli, A. La calidad de la formación inicial docente en Chile: La perspectiva de los profesores principiantes. Calid. Educ. 2013, 39, 117-154. [CrossRef]

29. Organization for Economic Cooperation and Development (OECD). Teaching and Learning International Survey (TALIS); OCED: Paris, France, 2019.

30. Calvo, M.; Verdugo, M.A.; Amor, A.M. La participación familiar es un requisito imprescindible para una escuela inclusiva. Rev. Latinoam. Educ. Inclusiva 2016, 10, 99-113. [CrossRef]

31. Darling-Hammond, L. El Derecho de Aprender. Crear Buenas Escuelas Para Todos; Ariel: Barcelona, Spain, 2001.

32. Finkelstein, S.; Sharma, U.; Furlonger, B. The inclusive practices of classroom teachers: A scoping review and thematic analysis. Int. J. Incl. Educ. 2019. [CrossRef]

33. Forlin, C.; Loreman, T.; Sharma, U. A system-wide professional learning approach about inclusion for teachers in Hong Kong. Asia-Pac. J. Teach. Educ. 2014, 42, 247-260. [CrossRef]

34. Ainscow, M.; Sandill, A. Developing Inclusive Education Systems: The Role of Organisational Cultures and Leadership. Int. J. Incl. Educ. 2010, 14, 401-416. [CrossRef]

35. Büssing, A.G.; Menzel, S.; Schnieders, M.; Beckmann, V.; Basten, M. Values and beliefs as predictors of pre-service teachers' enjoyment of teaching in inclusive settings. J. Res. Spec. Educ. Needs 2019, 19, 8-23. [CrossRef]

36. European Agency for Special Needs and Inclusive Education. Teacher Professional Learning for Inclusion: Literature Review; De Vroey, A., Symeonidou, S., Watkins, A., Eds.; European Agency for Special Needs and Inclusive Education: Odense, Denmark, 2019.

37. Avramidis, E.; Norwich, B. Teachers' attitudes towards integration/inclusion: A review of the literature. Eur. J. Spec. Needs Educ. 2002, 17, 129-147. [CrossRef]

38. Forlin, C.; Cedillo, I.G.; Romero-Contreras, S.; Fletcher, T.; Rodríguez Hernández, H.J. Inclusion in Mexico: Ensuring supportive attitudes by newly graduated teachers. Int. J. Incl. Educ. 2010, 14, 723-739. [CrossRef]

39. De Boer, A.; Jan Pijl, S.; Minnaert, A.; Tied, F. Regular primary schoolteachers' attitudes towards inclusive education: A review of the literature. Int. J. Incl. Educ. 2011, 15, 331-353. [CrossRef]

40. Saloviita, T. Attitudes of Teachers Towards Inclusive Education in Finland. Scand. J. Educ. Res. 2020, 64, 270-282. [CrossRef]

41. Bandura, A. Self- efficacy: Towards a unifying theory of behavioral change. Psychol. Rev. 1997, 84, 191-215. [CrossRef]

42. Bandura, A. Adolescent Development from an Agentic Perspective. In Self-Efficacy Beliefs of Adolescents; Urdan, T., Pajares, F., Eds.; Information Age publishing: Greenwich, CT, USA, 2006; pp. 1-43.

43. Woolfolk, A. Educational Psychology; Pearson Education, Inc.: London, UK, 2007.

44. Paneque, O.M.; Barbetta, P.M. A study of teacher efficacy of special education teachers of english language learners with disabilities. Biling. Res. J. 2006, 30, 171-193. [CrossRef]

45. Sharma, U.; Loreman, T.; Forlin, C. Measuring teacher efficacy to implement inclusive practices. J. Res. Spec. Educ. Needs 2012, 12, 12-21. [CrossRef]

46. Sharma, U.; Sokal, L. The impact of a teacher education course on pre-service teachers' beliefs about inclusion: An international comparison. J. Res. Spec. Educ. Needs 2015, 15, 276-284. [CrossRef]

47. Savolainen, H.; Malinen, O.; Schwab, S. Teacher efficacy predicts teachers' attitudes towards inclusion-A longitudinal crosslagged analysis. Int. J. Incl. Educ. 2020, 1-15. [CrossRef] 
48. Sharma, U.; Sindu, G. Understanding teacher self-efficacy to teach in inclusive classrooms. In Asia-Pacific Perspectives on Teacher Self-Efficacy; Garvis, S., Pendergast, D., Eds.; Brill Sense: Rotterdam, The Netherlands, 2016; pp. 37-51.

49. Savolainen, H.; Engelbrecht, P.; Nel, M.; Malinen, O. Understanding teachers' attitudes and self-efficacy in inclusive education: Implication for preservice and in-service teacher education. Eur. J. Spec. Needs Educ. 2012, 27, 51-68. [CrossRef]

50. Hofman, R.H.; Kilimo, J.S. Teachers' attitudes and self-efficacy towards inclusion of pupils with disabilities in Tanzanian schools. J. Educ. Train. 2014, 1, 177-198. [CrossRef]

51. Weisel, A.; Dror, O. School climate, sense of efficacy and Israeli teachers' attitudes toward inclusion of students with special needs. Educ. Citizsh. Soc. Justice 2006, 1, 157-174. [CrossRef]

52. Ajzen, I. The Theory of Planned Behaviour: Reactions and Reflections. Psychol. Health 2011, 9, 1113-1127. [CrossRef]

53. San Martin, C.; Calvo, R.; Sharma, U.; Ramirez, C.; Muñoz, Y. Measuring in-service educators' intention to teach in inclusive classrooms, attitudes for inclusion and self-efficacy for inclusive practices in Chile. Int. J. Disabil. Dev. Educ. 2021. in review.

54. Hellmich, F.; Löper, M.F.; Görel, G. The role of primary school teachers' attitudes and selfefficacy beliefs for everyday practices in inclusive classrooms-a study on the verification of the 'Theory of Planned Behaviour'. J. Res. Spec. Educ. Needs 2019, 19, 36-48. [CrossRef]

55. MacFarlane, K.; Woolfson, L. Teacher attitudes and behavior toward the inclusion of children with social, emotional and behavioral difficulties in mainstream schools: An application of the theory of planned behavior. Teach. Teach. Educ. 2013, 29, 46-52. [CrossRef]

56. Opoku, M.; Cuskelly, M.; Pedersen, S.; Rayner, C. Applying the theory of planned behaviour in assessments of teachers' intentions towards practicing inclusive education: A scoping review. Eur. J. Spec. Needs Educ. 2020, 1, 16. [CrossRef]

57. Sharma, U.; Simi, J.; Forlin, C. Preparedness of Pre-Service Teachers for Inclusive Education in the Solomon Islands. Aust. J. Teach. Educ. 2015, 40, n5. [CrossRef]

58. Sharma, U.; Aiello, P.; Pace, E.M.; Round, P.; Subban, P. In-service Teachers' Attitudes, Concerns, Efficacy and Intentions to Teach in Inclusive Classrooms: An International Comparison of Australian and Italian Teachers. Eur. J. Spec. Needs Educ. 2018, 33, 437-446. [CrossRef]

59. Sharma, U.; Jacobs, D.K. Predicting in-service educators' intentions to teach in inclusive classrooms in India and Australia. Teach. Teach. Educ. 2016, 55, 13-23. [CrossRef]

60. Song, J.; Sharma, U.; Choi, H. Impact of teacher education on pre-service regular school teachers' attitudes, intentions, concerns and self-efficacy about inclusive education in South Korea. Teach. Teach. Educ. 2019, 86, 102901. [CrossRef]

61. Wilson, C.; Woolfson, L.M.; Durkin, K.; Elliott, M.A. The Impact of Social Cognitive and Personality Factors on Teachers' Reported Inclusive Behaviour. Br. J. Educ. Psychol. 2016, 86, 461-480. [CrossRef]

62. Yan, Z.; Sin, K.F. Inclusive education: Teachers' intentions and behaviour analysed from the viewpoint of the theory of planned behaviour. Int. J. Incl. Educ. 2014, 18, 72-85. [CrossRef]

63. Wang, L.; Wang, M.; Wen, H. Teaching Practice of Physical Education Teachers for Students with Special Needs: An Application of the Theory of Planned Behaviour. Int. J. Disabil. Dev. Educ. 2015, 62, 590-607. [CrossRef]

64. Wilson, C.; Marks Woolfson, L.; Durkin, K. School environment and mastery experience as predictors of teachers' self-efficacy beliefs towards inclusive teaching. Int. J. Incl. Educ. 2018. [CrossRef]

65. Opoku, M.P.; Cuskelly, M.; Pedersen, S.J.; Rayner, C.S. Attitudes and self-efficacy as significant predictors of intention of secondary school teachers towards the implementation of inclusive education in Ghana. Eur. J. Psychol. Educ. 2020, 1-19. [CrossRef]

66. Mata, L.; Clipa, O.; Lazar, I. Measuring In-Service Teachers' Attitudes Towards Inclusive Education. Int. J. Disabil. Dev. Educ. 2020, 67, 135-150. [CrossRef]

67. Kuyini, A.B.; Desai, I.; Sharma, U. Teachers' self-efficacy beliefs, attitudes and concerns about implementing inclusive education in Ghana. Int. J. Incl. Educ. 2018, 1-18. [CrossRef]

68. Schmidt, M.; Vrhovnik, K. Attitudes of teachers towards the inclusion of children with special needs in primary and secondary schools. Hrvat. Rev. Za Rehabil. Istraživanja 2015, 51, 16-30.

69. Avramidis, E.; Bayliss, P.; Burden, R. Inclusion in action: An in-depth case study of an effective inclusive secondary school in the south-west of England. Int. J. Incl. Educ. 2002, 6, 143-163. [CrossRef]

70. Leatherman, J.M.; Niemeyer, J.A. Teachers' attitudes toward inclusion: Factors influencing classroom practice. J. Early Child. Teach. Educ. 2005, 26, 23-36. [CrossRef]

71. Avramidis, E.; Bayliss, P.; Burden, R. Student teachers' attitudes towards the inclusion of children with special educational needs in the ordinary school. Teach. Teach. Educ. 2000, 16, 277-293. [CrossRef]

72. Dorji, R.; Bailey, J.; Paterson, D.; Graham, L.; Miller, J. Bhutanese teachers' attitudes towards inclusive education. Int. J. Incl. Educ. 2019, 1-20. [CrossRef]

73. Peebles, J.; Mendaglio, S. The impact of direct experience on preservice teachers' self-efficacy for teaching in inclusive classrooms. Int. J. Incl. Educ. 2014, 18, 1321-1336. [CrossRef]

74. Kuitinnen, E. Inclusive Education from Teachers' Perspective: Exploring Chilean Teachers' Attitudes and Self-Efficacy. Master's Thesis, University of Jyväskylä Repository, Jyväskylä, Finland, 2017. Available online: https://jyx.jyu.fi/bitstream/handle/1234 56789/56467/URN:NBN:fi:jyu-201712204823.pdf?sequence=1 (accessed on 3 November 2020).

75. Malinen, O.P.; Savolainen, H.; Engelbrecht, P.; Xu, J.; Nel, M.; Nel, N.; Tlale, D. Exploring teacher self-efficacy for inclusive practices in three diverse countries. Teach. Teach. Educ. 2013, 33, 34-44. [CrossRef] 
76. Alghazo, E.M.; Naggar Gaad, E.E. General education teachers in the United Arab Emirates and their acceptance of the inclusion of students with disabilities. Br. J. Spec. Educ. 2004, 31, 94-99. [CrossRef]

77. Boyle, C.; Topping, K.; Jindal-Snape, D. Teachers' attitudes towards inclusion in high schools. Teach. Teach. 2013, 19, 527-542. [CrossRef]

78. Ahmmed, M.; Sharma, U.; Deppeler, J. Variables affecting teachers' intentions to include students with disabilities in regular primary schools in Bangladesh. Disabil. Soc. 2013, 29, 317-331. [CrossRef]

79. Monsen, J.J.; Ewing, D.L.; Kwoka, M. Teachers' attitudes towards inclusion, perceived adequacy of support and classroom learning environment. Learn. Environ. Res. 2014, 17, 113-126. [CrossRef]

80. Chao, C.; Sze, W.; Chow, E.; Forlin, C.; Ho, F. Improving teachers' self-efficacy in applying teaching and learning strategies and classroom management to students with special education needs in Hong Kong. Teach. Teach. Educ. 2017, 66, 360-369. [CrossRef]

81. Pas, E.T.; Bradshaw, C.P.; Hershfeldt, P.A. Teacher and school level predictors of teacher efficacy and burnout: Identifying potential areas for support. J. Sch. Psychol. 2012, 50, 129-145. [CrossRef]

82. Avramidis, E.; Kalyva, E. The influence of teaching experience and professional development on Greek teachers' attitudes towards inclusion. Eur. J. Spec. Needs Educ. 2007, 22, 367-389. [CrossRef]

83. Sari, H. The influence of an in-service teacher training (INSET) programme on attitudes towards inclusion by regular classroom teachers who teach deaf students in primary schools in Turkey. Deaf. Educ. Int. 2007, 9, 131-146. [CrossRef]

84. Yada, A.; Tolvanen, A.; Savolainen, H. Teachers' attitudes and self-efficacy on implementing inclusive education in Japan and Finland: A comparative study using multi-group structural equation modelling. Teach. Teach. Educ. 2018, 75, 343-355. [CrossRef]

85. Wolters, C.; Daugherty, S. Goal structures and teachers' sense of efficacy: Their relation and association to teaching experience and academic level. J. Educ. Psychol. 2007, 99, 181-193. [CrossRef]

86. Malinen, O.; Savolainen, H.; Xu, J. Beijing in-service teachers' self-efficacy and attitudes towards inclusive education. Teach. Teach Educ. 2012, 28, 526-534. [CrossRef]

87. Miesera, S.; DeVries, J.; Jungjohann, J.; Gebhardt, M. Correlation between attitudes, concerns, self-efficacy and teaching intentions in inclusive education evidence from German pre-service teachers using international scales. J. Res. Spec. Educ. Needs 2019, 19, 103-114. [CrossRef]

88. Sokal, L.; Sharma, U. Canadian in-service teachers' concerns, efficacy, and attitudes about inclusive teaching. Except Educ. Int. 2014, 23, 59-71. [CrossRef]

89. Kinsella, W.; Senior, J. Developing inclusive schools: A systemic approach. Int. J. Incl. Educ. 2008, 12, 651-665. [CrossRef]

90. Romero-Contreras, S.; Garcia-Cedillo, I.; Forlin, C.; Lomelí-Hernández, K.A. Preparing teachers for inclusion in Mexico: How effective is this process? J. Educ. Teach. 2013, 39, 509-522. [CrossRef]

91. Carrasco, C.; Luzoón, A. Respeto docente y convivencia escolar: Significados y estrategias en escuelas chilenas. Psicoperspectivas 2019, 18, 1-11.

92. Ross-Hill, R. Teacher attitude towards inclusion practices and special needs student. J. Res. Spec. Educ. Needs 2009, 9, 188-198 [CrossRef]

93. Ritter, R.; Wehner, A.; Lohaus, G.; Krämer, P. Effect of same-discipline compared to different-discipline collaboration on teacher trainees' attitudes towards inclusive education and their collaboration skills. Teach. Teach. Educ. 2020, 87, 102955. [CrossRef]

94. Kurniawati, F.; de Boer, A.; Minnaert, A.; Mangunsong, F. Evaluating the effect of a teacher training programme on the primary teachers' attitudes, knowledge, and teaching strategies regarding special educational needs. Educ. Psychol. 2017, 37, $287-297$. [CrossRef]

95. Chan, D.W. General, collective, and domain-specific teacher self-efficacy among Chinese prospective and in-service teachers in Hong Kong. Teach. Teach. Educ. 2008, 24, 1057-1069. [CrossRef]

96. Klassen, R.; Chiu, M. Effects on teacher efficacy and job satisfaction: Teacher gender, years of experience, and job stress. J. Educ. Psychol. 2010, 102, 741-756. [CrossRef]

97. Rojas, M. Inclusión Social en las Escuelas: Estudio de Prácticas Pedagógicas Inclusivas y Proyecciones Para Enfrentar un Escenario Sin Copago y Selección Escolar. 2016. Available online: https://centroestudios.mineduc.cl/wp-content/uploads/sites /100/2017 /07/INFORME-FINAL-F911429.pdf (accessed on 23 November 2020).

98. Ahsan, M.T.; Deppeler, J.M.; Sharma, U. Predicting pre-service teachers' preparedness for inclusive education: Bangladeshi pre-service teachers' attitudes and perceived teaching-efficacy for inclusive education. Camb. J. Educ. 2013, 43, 517-535. [CrossRef] 